\title{
Mesquite, Tobosagrass, and Common Broomweed Responses to Fire Season and Intensity
}

\author{
R. J. Ansley, ${ }^{1}$ W. E. Pinchak, ${ }^{1}$ and D. L. Jones ${ }^{2}$ \\ Authors are ${ }^{1}$ Professor and ${ }^{2}$ Research Technician, Texas AgriLife Research, PO Box 1658, Vernon, TX 76385-1658, USA.
}

\begin{abstract}
There has been increasing interest in the use of summer fires to limit woody plant encroachment on grasslands, but information regarding effects of such fires on perennial grass recovery and annual forb production is also needed. Our objective was to examine effects of fire seasonality and intensity on the woody legume honey mesquite (Prosopis glandulosa Torr.), the $\mathrm{C}_{4}$ midgrass tobosagrass (Pleuraphis mutica Buckl.), and the annual forb common broomweed (Amphiachyris dracunculoides [DC.] Nutt.). Treatments included summer fires, high-intensity winter fires, low-intensity winter fires, and no burn in replicated plots. None of the fire treatments caused whole-plant mortality (root kill) in mesquite. Mesquite aboveground mortality (top kill) was much greater after summer and high-intensity winter fires than low-intensity winter fires. Tobosagrass total yield (live + dead) was lower following summer fires and was not enhanced by any of the fire treatments for two growing seasons postfire when compared to the no-burn condition. However, tobosagrass live yield was $40 \%$ greater in the high-intensity winter fire treatment than the no-burn condition the first summer postfire and recovered in the other fire treatments by the end of the first growing season postfire. Tobosagrass percentage of live tissue was greatest in the summer fire treatment at the end of each of the two growing seasons postfire. Common broomweed cover increased in the summer fire treatment and decreased in both winter fire treatments relative to the no-burn condition by the end of the first growing season postfire. Summer fire offered no clear advantage over high-intensity winter fire with respect to mesquite suppression. However, the increase in late-season tobosagrass percentage live tissue caused by summer fire may be advantageous for forage quality. In addition, patch burning summer fires to increase broomweed cover in selected areas may be useful for wildlife habitat.
\end{abstract}

\section{Resumen}

Ha habido un creciente interés en el uso de fuego de verano para limitar el incremento de plantas leñosas en áreas de pastizal, pero se necesita información sobre el efecto de las quemas de verano en la recuperación de las gramíneas perennes y la producción de herbáceas anuales. Nuestro objetivo fue, evaluar el efecto de la estación y la intensidad del fuego sobre el mezquite (Prosopis glandulosa Torr.), el pasto tobosa $\mathrm{C}_{4}$ (Pleuraphis mutica Buckl.), y la herbácea anual escobilla común (Amphiachyris dracunculoides [DC.] Nutt.). Los tratamientos contemplados fueron: quema de verano, quema de invierno de alta y baja intensidad, y el control sin quema en parcelas repetidas. Ninguno de los tratamientos de quema causó la muerte total de plantas de mezquite (muerte de la raíz). La mortalidad de la parte aérea del mezquite fue superior después de las quemas de verano e invierno con alta-intensidad comparadas con las quemas de invierno baja-intensidad. El forraje disponible total del pasto tobosa (forraje vivo y muerto) fue menor después de la quema de verano, sin incrementarse por el efecto de los tratamientos de quema después de dos estaciones de crecimiento, comparado con el control sin quema. Sin embargo, el rendimiento de forraje vivo fue $40 \%$ mayor en los tratamientos de quema invernal de alta intensidad comparada con el control sin quema, el primer verano. El porcentaje de forraje vivo del pasto tobosa fue mayor en los tratamientos de quema de verano al final de de la época de crecimiento. La cobertura de la escobilla común se incrementó en los tratamientos de quema de verano y disminuyó en los tratamientos de quema invernal de alta y baja intensidad, en relación al control sin quema para el final de la primera época de crecimiento después de la quema. La quema de verano no ofreció una ventaja clara sobre la quema invernal de alta intensidad en relación a la eliminación del mezquite. Sin embargo, el incremento en el porcentaje de forraje verde del pasto tobosa, debido a la quema de verano puede ser benéfico para la calidad del forraje, adicionalmente, la quema de verano en partes para incrementar la cobertura de la escobilla común en áreas seleccionadas puede ser útil para el hábitat de la fauna silvestre.

Key Words: burn season, fire temperature, savanna, summer fire, woody plant encroachment

\section{INTRODUCTION}

Research was funded in part by the USDA-NRICGP Agricultural Systems Grants 94-37211. 1172 and 98-35108-6491, and Texas Agrilife Research under Project H-8310. The Y Ranch, Paducah, TX, USA, provided the land area for this research.

Correspondence: R. James Ansley, Texas Agrilife Research, PO Box 1658, 11708 Hwy 70 South, Vernon, TX 76385, USA. Email: r-ansley@tamu.edu

Manuscript received 23 May 2008; manuscript accepted 19 August 2008.
The role that fire plays in maintaining grasslands and limiting encroachment of woody plants has been the subject of worldwide interest (Axelrod 1985; Anderson 1990; McPherson 1995; Van Auken 2000; Bond et al. 2005; Briggs et al. 2005). In temperate grasslands, prescribed fires are often conducted during the dormant season (winter or early spring; Anderson et al. 1970; Wright and Bailey 1982; van Wilgen et al. 1990), but 
there is increased interest in the application of summer fires in woody encroached grasslands, because the greater intensity and/ or longer duration of high temperatures of summer fires inflict greater damage to woody plants and cacti than caused by winter fires (Cable 1965; Trollope 1987; Ansley and Taylor 2004; Ansley and Castellano 2007b). In addition, lightning-caused summer fires are a natural component of some grassland ecosystems such as the Great Plains of the United States (Axelrod 1985; Anderson 1990; Engle and Bidwell 2001; Ansley and Castellano 2007c). However, before summer fires are accepted as a management option, more information is needed regarding potential negative effects of summer fires, including damage to nontarget grass species and increases in undesirable annual forb species (Biondini et al. 1989; Drewa and Havstad 2001; Fuhlendorf and Engle 2004; Ansley et al. 2006).

Fire is hypothesized to have a negative effect on grass species that are physiologically active at the time of burning (Daubenmire 1968; Howe 1994a). Thus, late-winter or spring fires may adversely affect $\mathrm{C}_{3}$ grasses and favor $\mathrm{C}_{4}$ grasses (Collins and Gibson 1990; Howe 1994b; Hartnett and Fay 1998), whereas summer fires may adversely affect $\mathrm{C}_{4}$ grasses and favor $C_{3}$ grasses (Steuter 1987; Trollope 1987; Howe 1995). Some studies have proposed that the reason $C_{4}$ grasses are more tolerant than $\mathrm{C}_{3}$ grasses to fire in any season is that they are better adapted, through greater $\mathrm{N}$-use efficiency and $\mathrm{N}$ storage properties, to the warm, dry, N-depleted edaphic conditions caused by frequent fires (Seastedt et al. 1991; Wedin and Tilman 1996; Blair et al. 1998).

In the southern Great Plains of the United States, summer fires are being considered for suppression of woody species such as honey mesquite (Prosopis glandulosa Torr.; Ansley and Jacoby 1998). In addition, the potential of low-intensity winter fires to shift woodland thickets to savannas was studied in Africa (Higgins et al. 2000). Low-intensity winter fires have been found to reduce the amount of foliage (i.e., partial "top kill") on honey mesquite, yet maintain apical dominance and preserve an arborescent physiognomy (Ansley and Jacoby 1998). Effects of such low-intensity winter fires on the herbaceous understory are largely unknown.

Tobosagrass (Pleuraphis mutica Buckl.) is a $\mathrm{C}_{4}$ rhizomatous perennial midgrass that occurs throughout the southwestern United States and northern Mexico (Neuenschwander et al. 1975; Stubbendieck et al. 1992). Tobosagrass produces a large amount of standing dead biomass that carries over from one year to the next (Wright 1973; Britton and Steuter 1983). The species is drought tolerant, but has limited value as livestock forage because of the rapid accumulation of standing dead (Herbel et al. 1972; Neuenschwander et al. 1975). Cattle will utilize tobosagrass after fire because most old growth is removed and new growth has higher protein content than unburned plants for a few months postfire (Dwyer 1972; Sharrow and Wright 1977; Britton and Steuter 1983). Recovery of tobosagrass total standing mass (live + dead) following late winter or early spring fires (March-April) has ranged from $2 \mathrm{yr}$ to $5 \mathrm{yr}$ (Dwyer 1972; Neuenschwander et al. 1978) and live yields have often exceeded unburned controls during the first year postfire (Wright 1969, 1973; Britton and Steuter 1983). Few studies have contrasted effects of summer and winter fires on tobosagrass total or live yields (Dwyer 1972; Neuenschwander et al. 1978).
Common or annual broomweed (Amphiachyris drancunculoides [DC.] Nutt.) occurs throughout the southern Great Plains of the United States (Stubbendieck et al. 1992) and coexists with mesquite and tobosagrass. Broomweed population levels are highly variable from year to year and depend on several climatic and geophysical factors (Towne and Owensby 1983). Seeds can germinate in the fall (September-November) or spring (March-April; Scifres et al. 1971). Factors that trigger germination are usually an opening of the woody overstory and/or grass and litter cover, coupled with abundant fall moisture (Britton and Wester 1995). In high population years broomweed can reduce herbaceous production (Britton and Wester 1995; Yoder et al. 1998). Limited work has been done contrasting the effect of summer and winter fires on broomweed populations (Ewing and Engle 1988). We would expect that late-summer (August to September) fires might stimulate broomweed production to a greater degree than would winterseason (January to March) fires if germination occurs in the fall between when summer and winter fires are applied. We also would expect that a high-intensity winter fire might be more effective than a low-intensity winter fire at controlling broomweed infestation if seedlings had emerged in the fall.

Here we investigate the effects of different-intensity winter fires and summer fire on mortality and growth of three different vegetative life forms: the woody shrub mesquite, the perennial midgrass tobosagrass, and the annual forb common broomweed. Tobosagrass occurs in monospecific patches and is thus evaluated in the same autecological manner as has been quantified for other grass species in the region that occur in monospecific patches (Ansley et al. 2006; Ansley and Castellano 2007a). Our first hypothesis was that summer fires would be more effective than winter fires, and high-intensity winter fires more effective than low-intensity winter fires on topkilling and root-killing mesquite. Our second hypothesis was that postfire recovery of tobosagrass, measured by yield amounts (live and total), would be greatest to least following low-intensity winter, high-intensity winter, and summer fires, respectively. Our third hypothesis was that broomweed populations would be greater following summer fires than winter fire or unburned treatments because of the opening of the woody overstory and decreasing herbaceous cover prior to broomweed germination. However, we were unable to predict where broomweed populations in unburned areas would rank relative to the winter fire treatments. This would depend on whether broomweed germination occurred before or after the winter fire treatments.

\section{METHODS AND MATERIALS}

Research was conducted on a 28-ha site on the Y Ranch near Paducah, Texas (lat $33^{\circ} 53^{\prime} \mathrm{N}$, long $100^{\circ} 00^{\prime} \mathrm{W}$; elevation $472 \mathrm{~m}$ ). Mean annual rainfall is $616 \mathrm{~mm}$. Soils are fine-silty, montmorillonitic, thermic Typic Haplusterts of the Hollister series. Vegetation was dominated by a mixture of native rangeland grasses and a mesquite overstory. Broadleaf forbs and other shrub species comprised $<10 \%$ of the species composition by weight. Most mesquite on the site were multistemmed regrowth, 2-4 m tall, and occurred at 200-500 trees $\cdot \mathrm{ha}^{-1}$. A top-killing mesquite herbicide was aerially 
sprayed on the site in 1983 . About $20 \%$ of the mesquite plants were few-stemmed and $<2 \mathrm{~m}$ tall and had emerged from seed since the herbicide treatment.

The site is dominated by perennial $\mathrm{C}_{4}$ grasses, tobosagrass, and buffalograss (Bouteloua dactyloides [Nutt.] J.T. Columbus). Other grasses on the site are $\mathrm{C}_{3}$ midgrass Texas wintergrass (Nassella leucotricha [Trin. and Rupr.] Pohl.), $\mathrm{C}_{3}$ annual grass Japanese brome (Bromus japonicus Thunb. ex Murray), and numerous $\mathrm{C}_{4}$ midgrasses. Averaged over all 12 plots 2 mo prior to summer fire treatment application, tobosagrass basal cover was $34.6 \% \pm 3.1$ (mean \pm standard error), buffalograss cover was $17.3 \% \pm 3.1, \mathrm{C}_{3}$ annual and perennial grass cover was $4.8 \% \pm 0.7$, forb cover was $1.6 \% \pm 0.3$, litter cover was $8.7 \% \pm 0.8$, and bare ground was $30.2 \% \pm 2.7$. All other grasses were $<1 \%$ each. Tobosagrass and buffalograss mostly occurred in monoculture patches. The site was fenced and livestock grazing was excluded from March 1994 to October 1996 to accumulate herbaceous fine fuel for the fires and to measure herbaceous responses during the first two postfire growing seasons. Prior to that the site had been continuously grazed at a moderate stocking rate $\left(\sim 10 \mathrm{ha} \cdot \mathrm{cow}^{-1}\right)$.

Fire treatments consisted of 1) high-intensity summer fire applied 20-21 September 1994; 2) high-intensity winter fire applied 31 January, 1 February, and 22 February 1995; 3) lowintensity winter fire applied 31 January, 24 February, and 10 March 1995; and 4) no burn. There were three replicate plots (each 1-2 ha) per treatment. All fires were conducted as head fires. We applied summer fires before the winter fires to compare vegetation responses within the same number of growing seasons postfire (as per Ansley et al. 2006; Ansley and Castellano 2007a, 2007b).

Intensity differences between high-intensity winter and lowintensity winter fire treatments were regulated by burning under different air temperatures and relative humidity levels (RH; Ansley et al. 1998). The high-intensity winter fires were conducted under relatively high air temperature and low RH, whereas the low-intensity winter fires were achieved by burning under higher RH and lower air temperature. Usually a single replicate plot was burned per day, because of time constraints related to travel to the site and set up and breakdown of the thermocouples. However, two summer replicates were burned the afternoon of 20 September 1994, and one replicate of each winter fire treatment was burned on the same day (31 January 1995), with the low-intensity fire applied in the morning and the high-intensity fire in the afternoon.

Air temperature, $\mathrm{RH}$, and wind speed were measured on site a few minutes prior to each fire. Herbaceous fine fuel amount (standing crop + litter) and moisture content were measured by harvesting within an hour prior to the burn five $0.25-\mathrm{m}^{2}$ quadrats of each of the three dominant herbaceous species (as determined by prior evaluation of species composition in each plot) that occurred in interstitial spaces between mesquite trees. Fire temperatures were measured within tobosagrass patches at 1 -s intervals at ground level and five heights above ground (0.1, $0.3,1,2$, and $3 \mathrm{~m}$ ) with the use of glass-insulated type $\mathrm{K}$ (Chromel-Alumel) thermocouple wire $(20$ American Wire Gauge; 0.8-mm diameter) overbraided with stainless steel and a Campbell CR7 data logger placed in a fireproof container

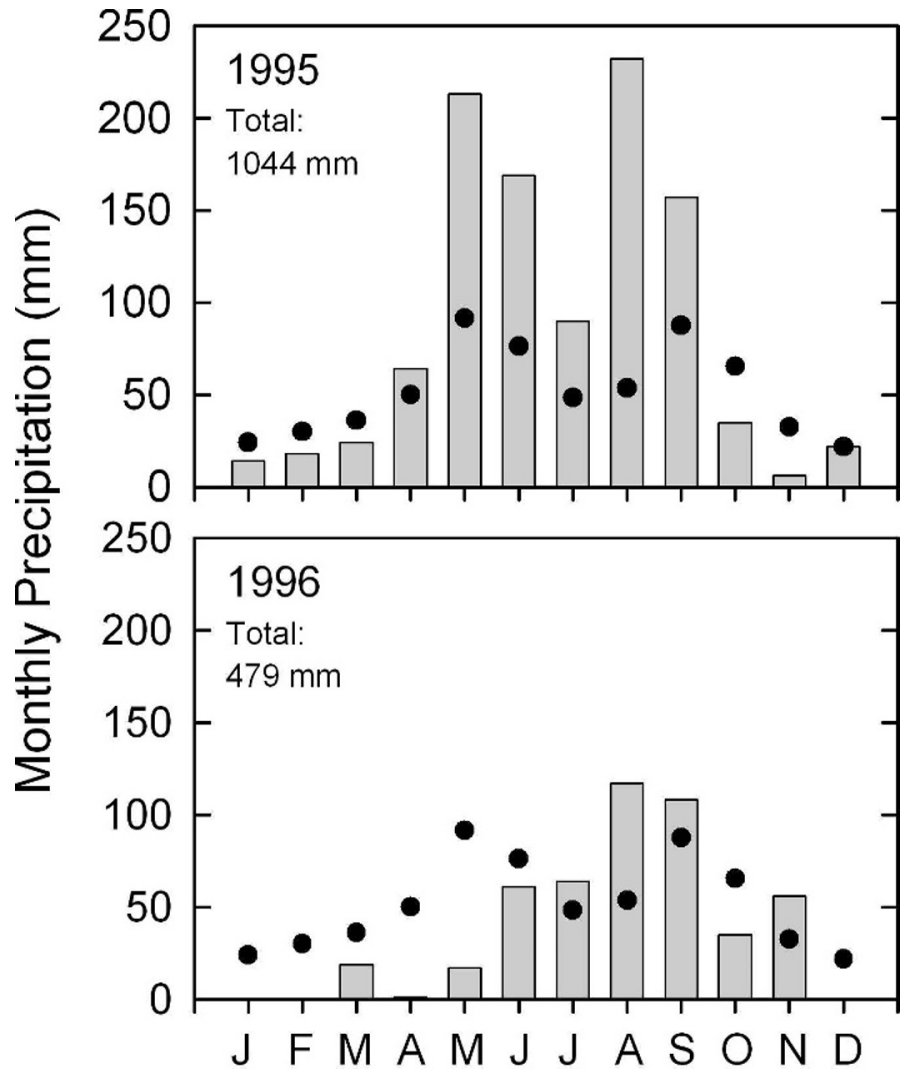

Figure 1. Monthly precipitation (bars) from 1995 to 1996 compared to 30-yr bimonthly average (filled circles; National Oceanic and Atmospheric Administration 2007).

(Ansley et al. 1998). Temperature was measured at 2-4 locations per replicate plot.

Flame length was estimated by videotaping the flame front as it passed 3-m-tall metal standards located in interstitial spaces between mesquite in each plot. Fire intensity was quantified with the use of the flame-length equation of Byram (1959): $I=$ $5.7 L^{2.2}$, where $I=$ fire-line intensity (British Thermal Units [BTU] $\cdot \mathrm{ft}^{-1} \cdot \mathrm{s}^{-1}$ ) and $L=$ flame length $(\mathrm{ft})$. Intensity values were converted from BTU $\cdot \mathrm{ft}^{-1} \cdot \mathrm{s}^{-1}$ to $\mathrm{kW} \cdot \mathrm{m}^{-1}$ (Roberts et al. 1988).

Precipitation data were averaged from nearby Crowell and Paducah National Oceanic and Atmospheric Administration sites (National Oceanic and Atmospheric Administration 2007). Precipitation was 104\% above normal from February through September 1995 during the first growing season postfire and the annual total was $69 \%$ above normal (Fig. 1). In contrast, precipitation was $68 \%$ below normal the first half of 1996 but the 1996 annual total was only $22 \%$ below normal.

\section{Vegetation Measurements}

Mesquite responses were evaluated at six permanently marked points (10 trees nearest each point) in each plot at the end of the first full growing season following the fire treatments. Each tree was classified as having whole-plant mortality (root kill), complete aboveground mortality (top kill), partial top kill, or no damage. Percent of canopy foliage reduction relative to the original canopy (of which the woody portion remained intact after the fire treatments) was visually estimated on partially top-killed trees. Data are reported as percent root kill, percent 
Table 1. Weather and fine fuel (tobosagrass) data prior to application of fire treatments. All values are means \pm standard error $(n=3)$. Means in each column followed by similar letters are not significantly different at $P \leq 0.05$.

\begin{tabular}{lccccc}
\hline \multicolumn{1}{c}{ Fire treatment } & Air temperature $\left({ }^{\circ} \mathrm{C}\right)$ & Relative humidity $(\%)$ & Wind speed $\left(\mathrm{m} \cdot \mathrm{s}^{-1}\right)$ & Fine fuel amount $\left(\mathrm{g} \cdot \mathrm{m}^{-2}\right)$ & Fine fuel moisture $(\%)$ \\
\hline Summer & $31.1 \pm 0.6 \mathrm{a}$ & $34.7 \pm 1.2 \mathrm{a}$ & $2.7 \pm 0.3 \mathrm{a}$ & $410 \pm 50 \mathrm{ab}$ & $25.0 \pm 2.3 \mathrm{a}$ \\
High-intensity winter & $23.4 \pm 2.7 \mathrm{~b}$ & $21.2 \pm 2.3 \mathrm{~b}$ & $3.3 \pm 0.8 \mathrm{a}$ & $458 \pm 40 \mathrm{a}$ & $13.2 \pm 1.2 \mathrm{~b}$ \\
Low-intensity winter & $15.3 \pm 1.7 \mathrm{c}$ & $36.0 \pm 2.6 \mathrm{a}$ & $3.1 \pm 0.8 \mathrm{a}$ & $271 \pm 66 \mathrm{~b}$ & $19.0 \pm 2.8 \mathrm{ab}$ \\
\hline
\end{tabular}

top kill, percent partially top killed, and percent canopy reduction of the entire stand when averaged over all trees (root killed, top killed, partially top killed, and undamaged).

Tobosagrass total and live yields were measured by clipping to ground level all aboveground tissue within a $0.25-\mathrm{m}^{2}$ quadrat that was randomly located in each of five monoculture patches (minimum patch size $15 \mathrm{~m}^{2}$ ) in each replicate plot. Samples were oven dried at $60^{\circ} \mathrm{C}$ to a constant weight and weighed. A subsample of each sample was used to separate live from dead tissue and estimate standing dead yield, live yield, and percentage of live tissue. Clipping was conducted three times per year, in spring, summer, and fall for two growing seasons following the fire treatments. Percent basal cover of tobosagrass and foliar cover of common broomweed were determined with the use of a $0.25-\mathrm{m}^{2}$ quadrat placed randomly in 15 locations in each plot, prior to fire treatments and in the spring and fall the first year following fire treatments. No cover data were collected in 1996. We measured foliar cover of broomweed because it was not possible to obtain accurate visual estimates of the basal cover of this single-stemmed forb in the $0.25-\mathrm{m}^{2}$ quadrat.

\section{Analysis}

A repeated-measures split-plot analysis (PROC GLM) with fire treatment as main plot and sample date as subplot with three replicates per treatment was used in the analysis of tobosagrass yield, tobosagrass basal cover, and common broomweed foliar cover (SAS 2003). All subsampling was averaged within each replicate plot prior to analysis. Following determination of significant treatment-by-sample-date interactions, within-date completely randomized design (CRD) analysis with fire treatment as main effect was conducted and means were separated with least significant difference (LSD; $P \leq 0.05$ ). A 1way CRD analysis with fire treatment as main effect (no-burn treatment not included) was used to assess treatment differences in weather conditions prior to burning (air temperature, $\mathrm{RH}$, wind speed, fine fuel amount, and moisture), fire behavior (temperature, flame length, fire intensity), and mesquite responses (root kill, top kill, partial top kill, and percent foliage reduction per stand). Means were separated with LSD $(P \leq 0.05)$. Percentage data were arcsine transformed prior to analysis.

\section{RESULTS}

\section{Fire Conditions and Behavior}

Weather conditions just prior to burning are reported in Table 1. As expected, air temperature was highest $(P \leq 0.05)$ in the summer fire treatment and lowest $(P \leq 0.05)$ in the lowintensity winter fire treatment. RH was lowest $(P \leq 0.05)$ in the high-intensity winter fire treatment. Herbaceous fine fuel was greater $(P \leq 0.05)$ in the high-intensity than the low-intensity winter fire treatment. Fine fuel moisture was greater $(P \leq 0.05)$ in the summer than the high-intensity winter fire treatment.

Mean peak fire temperature occurred at either $0.1 \mathrm{~m}$ or $0.3 \mathrm{~m}$ aboveground during all fires and was similar for all fire treatments (Table 2). Peak fire temperature at the soil surface was greater $(P \leq 0.05)$ in the high-intensity than the lowintensity winter fire treatment, with the summer fire treatment intermediate. As expected, flame lengths and fire-line intensities were greatest to least $(P \leq 0.05)$ in summer, high-intensity winter, and low-intensity winter fires.

\section{Fire Effects-Mesquite}

Mesquite root kill was $0 \%$ in all treatments. All of the mesquite trees in any of the three fire treatments were either completely top killed or partially top killed. Percentage of mesquite with complete top kill was similar in summer and high-intensity winter fire treatments, and was over three times greater in these treatments $(P \leq 0.05)$ than in the low-intensity winter fire treatment (Table 3). Percentage of mesquite partially top killed was greatest $(P \leq 0.05)$ in the low-intensity winter fire treatment. Stand-level mesquite canopy foliage reduction was $>93 \%$ in summer and high-intensity winter fires and was $64 \%$ in the low-intensity winter fire treatment.

\section{Fire Effects-Tobosagrass Yields}

In the first growing season postfire, tobosagrass total yield (live + dead) in both winter fire treatments increased to levels similar to the no-burn treatment by July (Fig. 2A). Total yield in summer fire treatment was lower than in the no-burn treatment throughout the first year postfire $(P \leq 0.05)$, and was lower $(P \leq 0.05)$ than both winter fire treatments in October of the first year. By the second year postfire, tobosagrass total yield was similar between the no-burn and both winter fire

Table 2. Fire behavior in tobosagrass interstitial spaces for summer, high-intensity winter, or low-intensity winter fire treatments. All values are means \pm standard error $(n=3)$. Means in each column followed by similar letters are not significantly different at $P \leq 0.05$.

\begin{tabular}{lcccc}
\hline \multicolumn{1}{c}{ Fire treatment } & Peak fire temperature all heights $\left({ }^{\circ} \mathrm{C}\right)$ & Peak fire temperature soil surface $\left({ }^{\circ} \mathrm{C}\right)$ & Flame length $(\mathrm{m})$ & Fire-line intensity $\left(\mathrm{kW} \cdot \mathrm{m}^{-1}\right)$ \\
\hline Summer & $653 \pm 28 \mathrm{a}$ & $469 \pm 26 \mathrm{ab}$ & $3.1 \pm 0.2 \mathrm{a}$ & $3248 \pm 372 \mathrm{a}$ \\
High-intensity winter & $710 \pm 12 \mathrm{a}$ & $532 \pm 18 \mathrm{a}$ & $2.1 \pm 0.1 \mathrm{~b}$ & $1437 \pm 79 \mathrm{~b}$ \\
Low-intensity winter & $702 \pm 35 \mathrm{a}$ & $406 \pm 48 \mathrm{~b}$ & $1.3 \pm 0.1 \mathrm{C}$ & $483 \pm 88 \mathrm{C}$ \\
\hline
\end{tabular}


Table 3. Mesquite responses to high-intensity summer, high-intensity winter, or low-intensity winter fire treatments at end of first growing season postfire. All values are means \pm standard error $(n=3)$. Means in each column followed by similar letters are not significantly different at $P \leq 0.05$.

\begin{tabular}{|c|c|c|c|}
\hline Fire treatment & $\begin{array}{l}\text { Mesquite with } \\
\text { complete top kill }\end{array}$ & $\begin{array}{l}\text { Mesquite partially } \\
\text { top killed }\end{array}$ & $\begin{array}{l}\text { Stand-level canopy } \\
\text { foliage reduction }\end{array}$ \\
\hline & \multicolumn{3}{|c|}{ 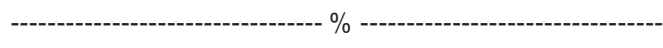 } \\
\hline Summer & $86.1 \pm 5.9 \mathrm{a}$ & $13.9 \pm 5.9 b$ & $97.9 \pm 1.2 \mathrm{a}$ \\
\hline High-intensity winter & $72.2 \pm 8.3 \mathrm{a}$ & $27.8 \pm 8.4 b$ & $93.8 \pm 1.8 \mathrm{a}$ \\
\hline Low-intensity winter & $18.4 \pm 7.0 \mathrm{~b}$ & $81.6 \pm 7.0 \mathrm{a}$ & $64.3 \pm 5.7 \mathrm{~b}$ \\
\hline
\end{tabular}

treatments by July, but was lower $(P \leq 0.05)$ in the summer fire treatment than the other three treatments in May and September. There was no difference in total yield between the two winter fire treatments on any sample date in either year. Total yield in the three fire treatments never exceeded that of the no-burn treatment during the study.

Tobosagrass standing dead biomass in the two winter fire treatments reached the level of the no-burn treatment by the end of the first year postfire with a sharp increase from July to October (Fig. 2B). Standing dead did not accumulate as rapidly in the summer fire treatment and was lower in this treatment $(P \leq 0.05)$ than the other three treatments by the end of the first growing season. In the second year postfire, differences in tobosagrass standing dead between treatments were very similar to the total yield results. In both years, tobosagrass standing dead in the no-burn treatment declined in midsummer (July) then increased in the fall.

Tobosagrass live yield was greater $(P \leq 0.05)$ in the highintensity winter fire treatment than the no-burn and summer fire treatments by July of the first growing season postfire (Fig. 3A). Live yield declined from July to October in all but the summer fire treatment. As a result, by October of the first year postfire, live yield was similar in all treatments. In the second year postfire, live yield remained $<50 \mathrm{~g} \cdot \mathrm{m}^{-2}$ in all treatments due to drought and was not different between treatments by midsummer.

Tobosagrass percentage live tissue was greater $(P \leq 0.05)$ in all three fire treatments than in the no-burn condition in May and July the first growing season postfire (Fig. 3B). By the end of the first growing season, percentage live tissue was over $50 \%$ greater $(P \leq 0.05)$ in the summer fire treatment than the other three treatments. During the second year postfire, percentage live tissue was $<22 \%$ in all treatments. However, similar to the first year, percentage live tissue was over $50 \%$ greater $(P \leq 0.05)$ in the summer fire treatment than the other treatments by growing season end.

\section{Fire Effects-Broomweed and Tobosagrass Cover}

Pretreatment broomweed foliar cover was near zero in all treatments (Fig. 4A). By May of the first growing season postfire, broomweed cover was greater $(P \leq 0.05)$ in the summer fire treatment and lower $(P \leq 0.05)$ in both winter fire treatments than in the no-burn treatment. By the end of the first growing season postfire, these differences between treatments became more pronounced $(P \leq 0.05)$, such that
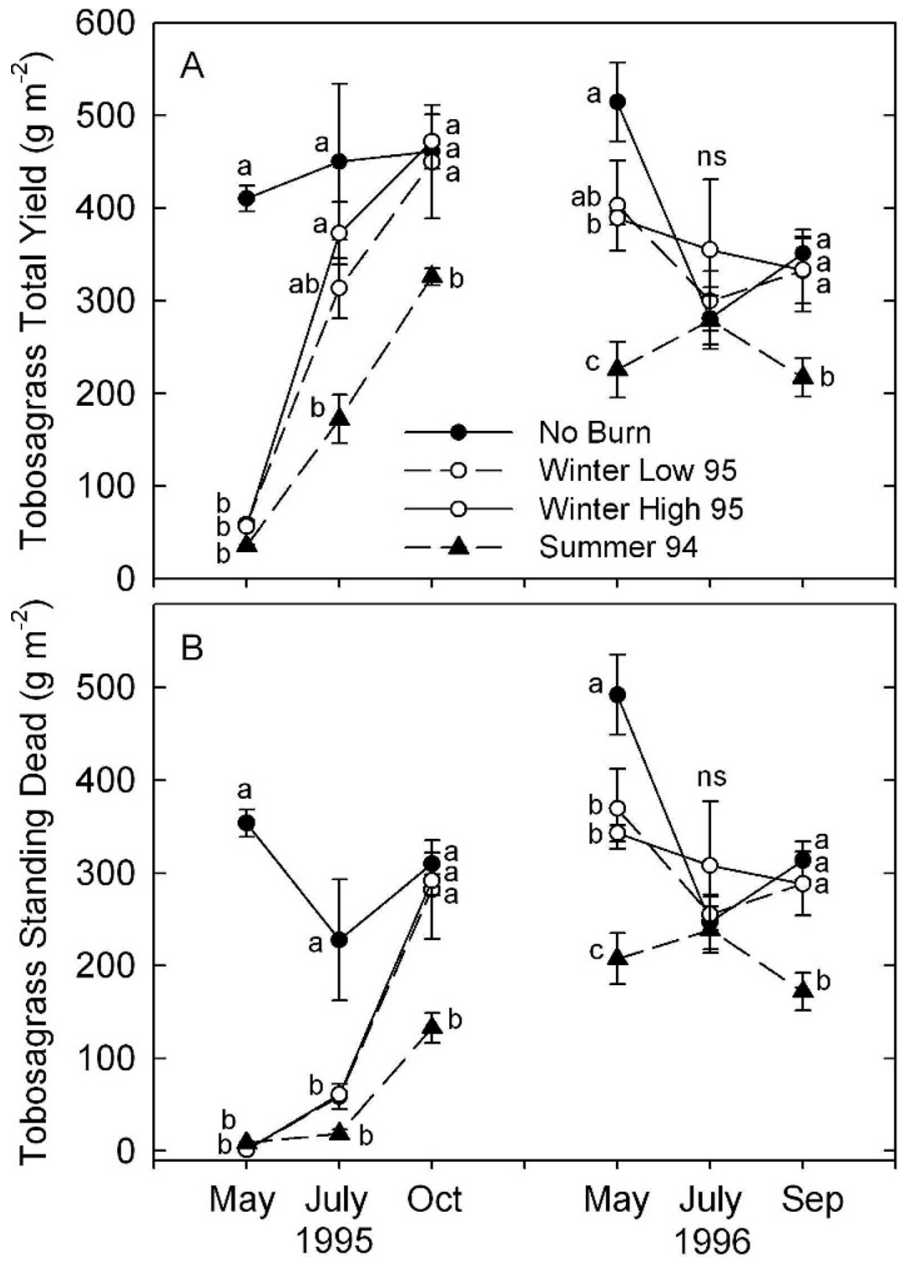

Figure 2. Tobosagrass total (live + dead) yield $(\mathbf{A})$ and standing dead yield $(\mathbf{B})$ during the first and second year postfire in each fire treatment. Winter Low = low-intensity winter fires; Winter High = high-intensity winter fires. Vertical bars are \pm standard error. Means within each sample date with similar letters are not significantly different at $P \leq 0.05$. $\mathrm{NS}=$ no significant differences.

broomweed cover was $43 \%$ in the summer fire treatment, yet was $<6 \%$ in the two winter fire treatments.

Pretreatment tobosagrass basal cover was similar in all treatments (Fig. 4B). By May of the first growing season postfire, tobosagrass cover decreased in all three fire treatments to levels below $(P \leq 0.05)$ the no-burn treatment $(15-20 \%$ vs. $39 \%)$. From May to October in the first growing season postfire, tobosagrass cover increased in all treatments, but gains were greatest in the two winter fire treatments. Thus, by the end of the first growing season postfire, tobosagrass cover was similar in the no-burn and winter fire treatments and much greater $(P \leq 0.05)$ in these treatments than in the summer fire treatment.

\section{DISCUSSION}

\section{Mesquite Responses}

In this study, high-intensity winter fires were as effective as summer fires in suppressing mesquite. Neither treatment rootkilled mesquite, but complete top kill was $>72 \%$ and stand 


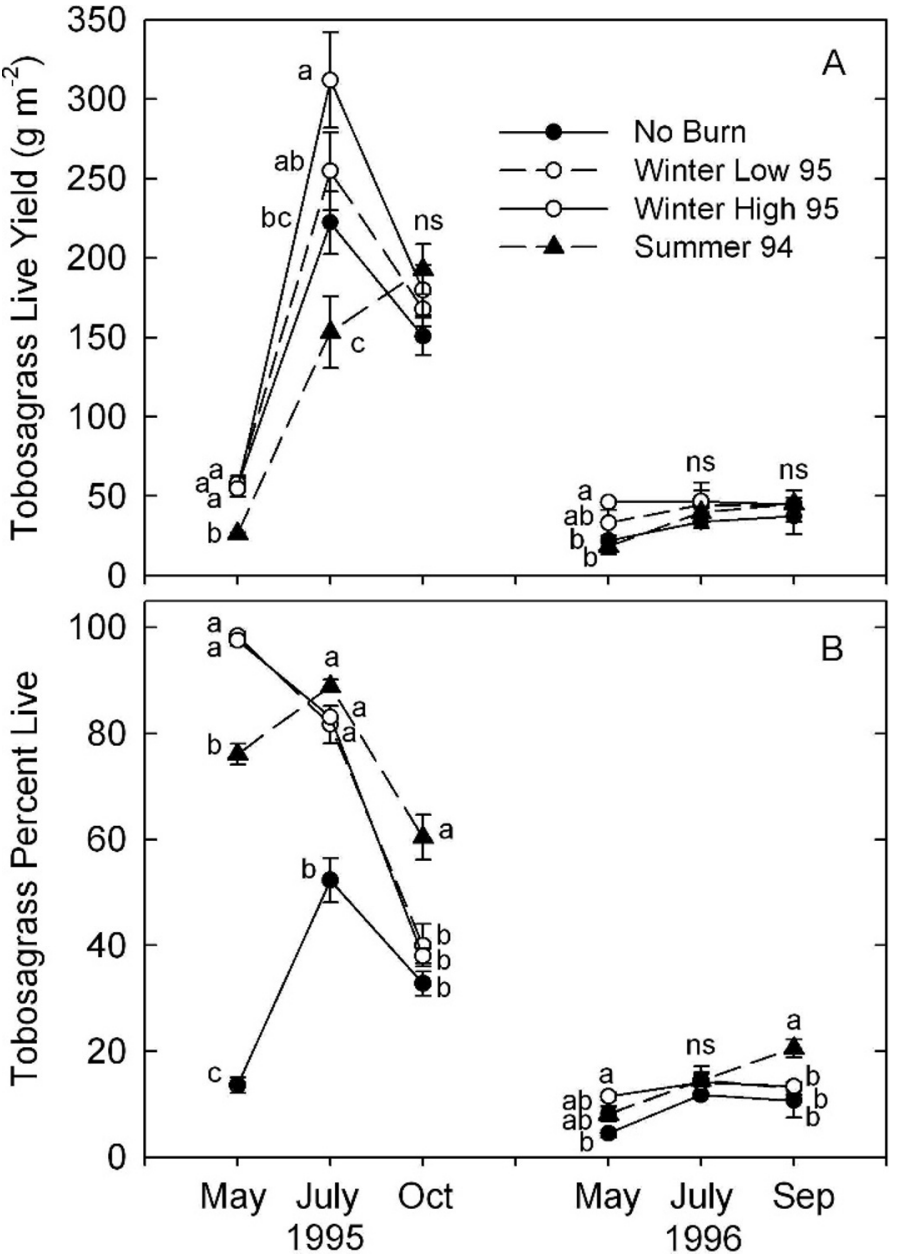

Figure 3. Tobosagrass live yield (A) and percentage live tissue (B) during the first and second year postfire in each fire treatment. Winter Low = low-intensity winter fires; Winter High = high intensity winter fires. Vertical bars are \pm standard error. Means within each sample date with similar letters are not significantly different at $P \leq 0.05$. NS $=$ no significant differences.

level canopy reduction was $>93 \%$ in both treatments. Thus, in this predominantly $\mathrm{C}_{4}$ short and midgrass ecosystem, summer fire offered no clear advantage over high-intensity winter fire with respect to mesquite suppression. The potential inhibitory effect of $\mathrm{C}_{3}$ grasses on winter fires that has been found in similar studies on sites $70 \mathrm{~km}$ east of the current study site (Ansley and Jacoby 1998; Ansley and Castellano 2007b) was not realized on this site because $<5 \%$ of the community were $\mathrm{C}_{3}$ grasses. Thus, under these conditions we reject our first hypothesis that summer fires would be more effective than high-intensity winter fires at top-killing and root-killing mesquite.

The large differences in flame length and fire-line intensity between high- and low-intensity winter fire treatments caused the differences in complete top kill between these treatments. Differences in fire-line intensity were attributed to differences in air temperature, $\mathrm{RH}$, and fine fuel amounts between these two treatments. Because over $80 \%$ of the trees in the lowintensity winter treatment were at least partially top killed, there was much less difference in stand-level canopy reduction between the winter fire treatments $(94 \%$ vs. $64 \%)$ than there
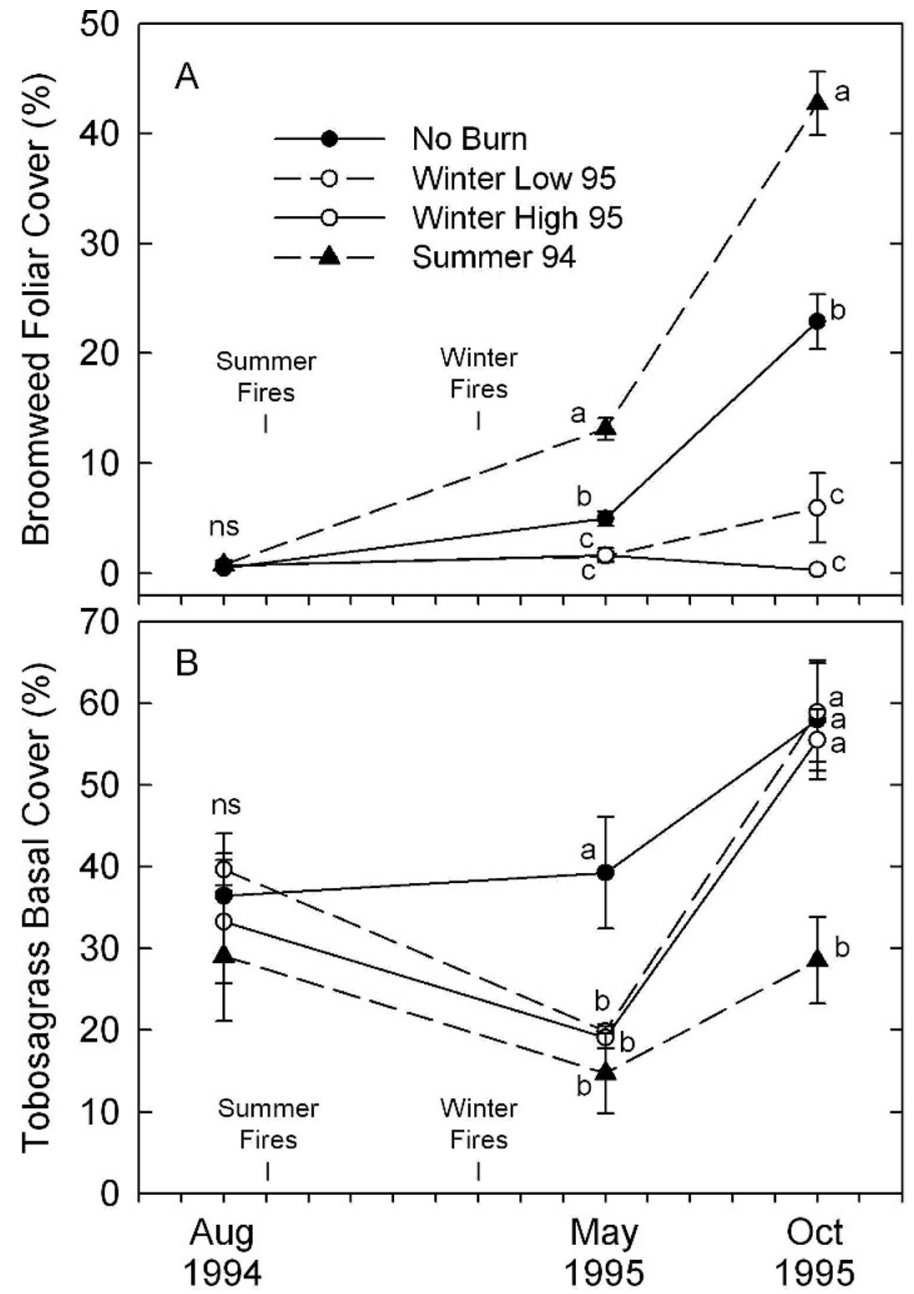

Figure 4. Common broomweed (A) and tobosagrass (B) foliar cover prior to the first fire treatments and on two dates during the first year postfire in each treatment. Winter Low =low-intensity winter fires; Winter High = high intensity winter fires. Vertical bars are \pm standard error. Means within each sample date with similar letters are not significantly different at $P \leq 0.05$. NS $=$ no significant differences.

was with respect to percent of trees with complete top kill ( $72 \%$ vs. $18 \%)$.

\section{Tobosagrass Responses}

The literature has reported tobosagrass yield responses to fire as either total or live yield. Care must be taken in interpreting these results, because, as our study and others have shown, postfire responses of these two variables are often quite different. Live yield has frequently been reported because of its importance as livestock forage (Wright 1973; Britton and Steuter 1983). However, because tobosagrass accumulates a large amount of standing dead biomass that carries over from one year to the next, total yield as an indicator of plant structure may be an important variable for soil erosion mitigation and habitat cover for small mammals or grounddwelling birds (Kaufman et al. 1990; Riggs et al. 1996). For example, Soutiere and Bolen (1976) found that ground-nesting success of the mourning dove (Zenaida macroura Linnaeus) was twice as high in unburned than burned tobosagrass rangeland for up to $3 \mathrm{yr}$ postfire. In Kansas, the number and 
success rate of avian nests of several grassland bird species were much greater in unburned than burned Conservation Reserve Program fields the summer after spring burning (Robel et al. 1998).

Tobosagrass total yield recovery was slower following summer fires than winter fires and had not fully recovered in the summer fire treatment by the end of the second growing season postfire. Tobosagrass rate of total yield recovery following summer fire was similar to sideoats grama (Bouteloua curtipendula [Michx.] Torr.; Ansley et al. 2006), but was slower than Texas wintergrass and buffalograss (Ansley and Castellano 2007a). In the only other study to contrast tobosagrass response to summer and winter fires, Dwyer (1972) found in New Mexico that it took $2 \mathrm{yr}$ for tobosagrass total yield to recover from a December fire, and 3 yr to recover from a June fire. They also found that during $5 \mathrm{yr}$ of postfire measurements, tobosagrass total yield was never greater in any fire treatment compared to the unburned control. Neuenschwander et al. (1978) found in west Texas that tobosagrass total yield required 4-5 yr to equal the unburned control.

In these studies a few conclusions can be made concerning total yield. First, total yield never exceeded the unburned control up to $5 \mathrm{yr}$ postfire. Second, recovery rates compared to unburned controls ranged from $1 \mathrm{yr}$ to $5 \mathrm{yr}$ and were somewhat dependent on precipitation patterns. Our study demonstrated the fastest rate of total yield recovery from winter fires, occurring by the end of the first growing season postfire. Precipitation from the February burn to October in our study was 104\% above normal. In contrast, in Dwyer's (1972) New Mexico study, tobosagrass total yield recovered within 2 yr postfire, even though average annual precipitation for those $2 \mathrm{yr}$ was slightly lower $(192 \mathrm{~mm})$ than the long-term $225-\mathrm{mm}$ average. We note that tobosagrass total yields in Dwyer's (1972) study were much lower $\left(100-200 \mathrm{~g} \cdot \mathrm{m}^{-2}\right)$ than at our site $\left(400-500 \mathrm{~g} \cdot \mathrm{m}^{-2}\right)$, which averages $616 \mathrm{~mm}$ of annual precipitation. Postfire precipitation patterns were not reported by Neuenschwander et al. (1978) except in the year of measurement following $5 \mathrm{yr}$ of temporally staggered fire treatments. Long-term average annual precipitation at their study site was $503 \mathrm{~mm}$. Thus, the 4-5 yr needed for total yield recovery is slower than expected when compared to our study and Dwyer's (1972) New Mexico study. Tobosagrass was exposed to "light" livestock grazing in Neuenschwander's et al. (1978) study, and this may have delayed total yield recovery rates because livestock would have been attracted to the burned plots (Fuhlendorf and Engle 2004).

With respect to live yield, our study partially agrees with Wright (1969, 1973), Neuenschwander et al. (1978), and Britton and Steuter (1983), who found that tobosagrass live yield increased compared to unburned plots the first growing season following a winter fire. Similar to our study, all these studies reported above-average precipitation during the first growing season postfire. However, these studies found live yields to be double (Wright 1969, 1973; Neuenschwander et al. 1978) or nearly triple (Britton and Steuter 1983) the control, whereas we found only a $40 \%$ increase in live yield compared to the no-burn treatment. In the Britton and Steuter (1983) study, precipitation from the February burn to June was $21 \%$ above normal, but was $99 \%$ above normal the preceding fall. In our study, precipitation from the February burn to June was
$72 \%$ above normal, so we expected a greater response in live yields. Other factors, such as soil type, topography, etc., may have caused the variation (Wright 1969; Neuenschwander and Wright 1984). The severe drought in the second year of our study limited live growth in all treatments and we did not find, as did Wright (1973), an elevation of tobosagrass live yield in the second year postfire.

In our study, tobosagrass live yield in the summer fire treatment recovered by the end of the first growing season postfire when compared to the no-burn treatment, but was never greater than in the no-burn treatment. We could not find other literature that reported tobosagrass live yields following summer fire. However, tobosagrass live-yield recovery following summer fire was faster than that reported for sideoats grama, Texas wintergrass, and buffalograss (Ansley et al. 2006; Ansley and Castellano 2007a).

Throughout our study there was no difference in tobosagrass total or live-yield responses between high-intensity and lowintensity winter fires. Thus, the low-intensity fire treatment offered no advantage in terms of accelerating tobosagrass postfire recovery. These results are similar to those of Roberts et al. (1988), who found that intensity of winter fires did not affect tobosagrass yields. Thus, we reject our second hypothesis because, although we did find that postfire recoveries of total and live yields were slowest following summer fires, there was no difference in recovery rates between high- and low-intensity winter fires.

\section{Live Yield and Potential Forage Quality}

Percentage live tissue was greater in the summer fire than the other treatments by the end of both the first and second postfire growing seasons. Thus, although late-season live yield was similar in all treatments, the greater percentage of live tissue in the summer fire treatment may have improved accessibility to live tissue by livestock. Britton and Steuter (1983) found that crude protein and tissue moisture content were greater for a few months after a February fire, but by July, these variables fell to levels similar to unburned old-growth tissue. Thus, winter fire had a significant but very transient effect on forage quality. Our finding that summer fire increased percentage of live tissue into the fall season in each of the first $2 \mathrm{yr}$ postfire suggests that this treatment enhanced forage quality, or at least accessibility to live tissue, for a longer postfire period than did the winter fires.

\section{Tobosagrass Responses in the No-Burn Treatment}

A substantial amount of tobosagrass standing dead biomass was carried over from one growing season to the next in the noburn treatment, as has been documented elsewhere (Neuenschwander et al. 1975). The no-burn plants experienced a midgrowing-season decline in standing dead in both years in spite of very different precipitation patterns. In the wet year, this decline coincided with the accumulation of new live growth from May to July. As a result, total yield remained level from spring to mid-summer as the decline in standing dead was offset by the increase in live yield. In contrast, in the dry year, the decline in standing dead yield was not matched by an increase in live yield. This process resulted in a substantial increase in percentage live tissue in this treatment in the wet year but not in the dry year. 


\section{Broomweed Responses}

This study revealed that in a year that had naturally abundant common broomweed production, burning in different seasons dramatically altered broomweed abundance. The order of broomweed abundance, as measured by canopy cover, supported our hypothesis with the exception that we did not see a difference in broomweed cover between the two winter fire treatments. The increase in broomweed cover in the summer fire treatment is similar to findings by Ewing and Engle (1988) and suggests that the opening of the mesquite canopy and herbaceous understory by summer fire may have triggered additional broomweed germination over what occurred in the no-burn plots. The mean fire temperature of $653^{\circ} \mathrm{C}$ at the soil surface in the summer fire treatment was apparently not sufficient to kill broomweed seeds that we presume were buried just below the soil surface.

The reduction of broomweed cover by both of the winter fire treatments compared to the no-burn control suggests that germination occurred in late fall before the winter fire treatments were applied and that both winter fire treatments killed most of the broomweed seedlings. The fact that there was no difference in broomweed cover between high- and lowintensity winter fires in our study suggests that the lowintensity fires had sufficiently high temperatures to kill the seedlings. Peak fire temperature on the soil surface was greater in the high-intensity winter than the low-intensity winter fire treatment, but remained $>400^{\circ} \mathrm{C}$ in the low-intensity winter treatment. Our results agree with those of Heirman and Wright (1973), who indicated in a west Texas study that early-spring fires reduced common broomweed production. Neuenschwander et al. (1978) found that, in a year when broomweed populations were low in unburned mesquite/tobosagrass communities, winter fire had no effect on broomweed populations the first year postfire. Results from these two Texas studies and ours disagree with those of Towne and Owensby (1983), who found that in northeastern Kansas winter (January) fire increased common broomweed density. Fall fires (October and November) in their study also increased broomweed density, but spring (April) fires had no effect compared to the control. Towne and Owensby (1983) indicated that common broomweed in their region did not germinate until after April, and attributed the increased density from fall and winter fires to the clearing of litter, which produced favorable conditions for broomweed establishment. Thus, the timing of emergence of common broomweed seedlings may have a profound effect on how seasonal fires affect postfire populations.

Numerous studies have documented an increase of forbs following fire (Engle and Bidwell 2001). However, in Tallgrass Prairie in Kansas most forb species decline in abundance with increasing spring fire frequency; only $\mathrm{N}$-fixing forbs increased with increased fire frequency (Hartnett and Fay 1998). Forb response to summer fire may depend on the species. For example, Biondini et al. (1989) found in the Northern Mixed Prairie of South Dakota that several forb species exhibited variable responses to seasonal fires. Their study compared spring (April), summer (August), and fall (October) fires. Only two of nine forb species evaluated had greater density after summer fires, whereas the density of the other forb species increased following spring or fall fires. Although Biondini et al.
(1989) did not evaluate common broomweed, our results strongly imply that in the southern Great Plains, common broomweed is stimulated by summer fire. We do not know how long the stimulation persists, but Engle et al. (2000) found in Oklahoma that common broomweed populations decreased with years after fire.

The tobosagrass monoculture patches in our study remained intact after the fire treatments, with little encroachment of other grass species evident. However, common broomweed was found within these patches, especially in the summer fire treatments. The greater broomweed cover in the no-burn and summer fire treatments may have reduced the rate of increase in tobosagrass production and cover in these treatments. From May to October 1995, rate of increase in tobosagrass cover was lower in the no-burn and the summer fire treatments than in the two winter fire treatments, thus supporting this likelihood.

\section{MANAGEMENT IMPLICATIONS}

In this study, high-intensity winter fires were as effective as summer fires in suppressing honey mesquite. Thus, summer fires may not be necessary in fuel types that have a dominant low-palatability $\mathrm{C}_{4}$ grass such as tobosagrass and a limited amount of $\mathrm{C}_{3}$ grasses, which would retard intensity of winter fires. Summer fire did not appear to have long-term negative effects on tobosagrass production and slightly increased the percentage of live tissue relative to the winter fire treatments at the end of each of the first two postfire growing seasons. Lowintensity winter fires may be suitable for management for mesquite savanna physiognomy to reduce foliage per tree, yet not completely top-kill trees and thus maintain apical dominance (Ansley and Jacoby 1998). However, when compared to high-intensity winter fires, the effect of lowintensity winter fires was limited to changes in mesquite physiognomy and did not accelerate postfire recovery of tobosagrass.

The increase in common broomweed following summer fires must be considered in management plans, as this will retard recovery of grass growth in the first year postfire. Common broomweed can also be an important attribute of wildlife habitat. Its structural characteristics can reduce temperature extremes and protect ground-dwelling birds such as the northern bobwhite quail (Colinus virginianus Linnaeus) from raptors (Johnson and Guthery 1988; Forrester et al. 1998; Kopp et al. 1998; Cram et al. 2002; Lusk et al. 2006). Common broomweed seeds are also an important food source for bobwhites and scaled quail (Callipepla squamata Vigors; Leif and Smith 1993; Guthery 2000). Thus, application of summer fires in patches may be a viable management tool to enhance ground-dwelling bird habitat via greater broomweed production.

\section{ACKNOWLEDGMENTS}

We thank Tim Tunnell, Betty Kramp, Gerral Schulz, and Ken Caldwell for their assistance in the field and laboratory. We wish to thank the Burgess Y Ranch for providing the land area to conduct this research. 


\section{LITERATURE CITED}

Anderson, K. L., E. F. Smith, and C. L. Owensby. 1970. Burning bluestem range. Journal of Range Management 23:81-92.

Anderson, R. C. 1990. The historic role of fire in the North American grassland. In: S. L. Collins and L. L. Wallace [EDS.]. Fire in North American tallgrass prairie. Norman, OK, USA: University of Oklahoma Press. p. 8-18.

Ansley, R. J., and M. J. Castellano. 2007a. Texas wintergrass and buffalograss response to seasonal fires and clipping. Rangeland Ecology \& Management 60:154-164.

Ansley, R. J., and M. J. Castellano. 2007b. Prickly pear cactus responses to summer and winter fires. Rangeland Ecology \& Management 60:244-252.

Ansley, R. J., and M. J. Castellano. 2007c. Effects of summer season fires on woody, succulent and graminoid vegetation in southern mixed prairie ecosystems. In: R. E. Masters and K. E. M. Galley [EDs.]. Fire in grassland and shrubland ecosystems. Proceedings of the Tall Timbers Fire Ecology Conference No. 23; 17-20 October 2005; Bartlesville, OK, USA. Lawrence, KS, USA: Allen Press. p. 63-70.

Ansley, R. J., M. J. Castellano, and W. E. Pinchak. 2006. Sideoats grama growth responses to seasonal fires and clipping. Rangeland Ecology \& Management 59:258-266.

Ansley, R. J., And P. W. Jacoby. 1998. Manipulation of fire intensity to achieve mesquite management goals in north Texas. In: T. L. Pruden and L. A. Brennan [EDS.]. Fire in ecosystem management: shifting the paradigm from suppression to prescription. Proceedings of the Tall Timbers Fire Ecology Conference No. 20; 7-10 May 1996; Boise, ID, USA. Lawrence, KS, USA: Allen Press. p. 195-204.

Ansley, R. J., D. L. Jones, T. R. Tunnell, B. A. Kramp, and P. W. Jacoby. 1998. Honey mesquite canopy responses to single winter fires: relation to fine fuel, weather and fire temperature. International Journal of Wildland Fire 8:241-252.

Ansley, R. J., ANd C. A. Taylor. 2004. The future of fire as a tool for managing brush. In: W. T. Hamilton, A. McGinty, D. N. Ueckert, C. W. Hanselka, and M. R. Lee [EDS.]. Brush management-past, present, future. College Station, TX, USA: Texas A\&M University Press. p. 200-210.

Axelrod, D. I. 1985. Rise of the grassland biome, central North America. Botanical Review 51:163-202.

Biondini, M. E., A. A. Steuter, And C. E. Grygiel. 1989. Seasonal fire on the diversity patterns, spatial distribution and community structure of forbs in the Northern Mixed prairie, USA. Vegetatio 85:21-31.

Blair, J. M., T. R. Seastedt, C. W. Rice, and R. M. Ramundo. 1998. Terrestrial nutrient cycling in tallgrass prairie. In: A. K. Knapp, J. M. Briggs, D. C. Hartnett, and S. L. Collins [EDS.]. Grassland dynamics-long term ecological research in Tallgrass prairie. New York, NY, USA: Oxford University Press. p. 222-243.

Bond, W. J., F. I. Woodward, and G. F. Midgley. 2005. The global distribution of ecosystems in a world without fire. New Phytologist 165:525-538.

Briggs, J. M., A. K. Knapp, J. M. Blair, J. L. Heisler, G. A. Hoch, M. S. Lett, and J. K. McCarron. 2005. An ecosystem in transition: causes and consequences of the conversion of mesic grassland to shrubland. BioScience 55:243-254.

Britton, C. M., and A. A. Steuter. 1983. Production and nutritional attributes of tobosagrass following burning. The Southwestern Naturalist 28:347-352.

Britton, C. M., And D. B. Wester. 1995. Ecology and control of annual broomweed. In: D. B. Wester and C. M. Britton [EDS.]. Texas Tech University Research Highlights. Volume 26. Lubbock, TX, USA: Texas Tech University Press. p. 9-11.

Brram, G. M. 1959. Combustion of forest fuels. In: K. P. Davis [ED.]. Forest fire: control and use. New York, NY, USA: McGraw-Hill. p. 61-89.

Cable, D. R. 1965. Damage to mesquite, Lehmann lovegrass and black grama by a hot June fire. Journal of Range Management 18:326-329.

Coluins, S. L., And D. J. GiBson. 1990. Effects of fire on community structure in tallgrass and mixed-grass prairie. In: S. L. Collins and L. L. Wallace [EDS.]. Fire in North American tallgrass prairie. Norman, OK, USA: University of Oklahoma Press. p. 81-98.

Cram, D. S., R. E. Masters, F. S. Guthery, D. M. Engle, and W. G. Montague. 2002. Northern bobwhite population and habitat response to pine-grassland restoration. Journal of Wildlife Management 66:1031-1039.

Daubenmire, R. 1968. Ecology of fire in grasslands. Advances in Ecological Research 5:207-266.
Drewa, P. B., and K. M. Havstad. 2001. Effects of fire, grazing, and the presence of shrubs on Chihuahuan desert grasslands. Journal of Arid Environments 48:429-443.

DWYER, D. D. 1972. Burning and nitrogen fertilization of tobosa grass. Las Cruces, NM, USA: New Mexico State University Agricultural Experiment Station Bulletin No. 595. 8 p.

Engle, D. M., And T. G. Bidwell. 2001. Viewpoint: the response of central North American prairies to seasonal fire. Journal of Range Management 54:210.

Engle, D. M., M. W. Palmer, J. S. Crockett, R. L. Mitchell, and R. Stevens. 2000. Influence of late season fire on early successional vegetation of an Oklahoma prairie. Journal of Vegetation Science 11:135-144.

Ewing, A. L., And D. M. Engle. 1988. Effects of late summer fire on tallgrass prairie microclimate and community composition. American Midland Naturalist 120:212-223.

Forrester, N. D., F. S. Guthery, S. D. Kopp, and W. E. Cohen. 1998. Operative temperature reduces habitat space for northern bobwhites. Journal of Wildlife Management 63:1506-1511.

Funlendorf, S. D., And D. M. Engle. 2004. Application of the fire-grazing interaction to restore a shifting mosaic on tallgrass prairie. Journal of Applied Ecology 41:604-614.

Guthery, F. S. 2000. On bobwhites. College Station, TX, USA: Texas A\&M University Press. $213 p$

Hartnett, D., and P. A. Fay. 1998. Plant populations-patterns and processes. In: A. K. Knapp, J. M. Briggs, D. C. Hartnett, and S. L. Collins [EDS.]. Grassland dynamics-long term ecological research in Tallgrass prairie. New York, NY, USA: Oxford University Press. p. 81-100.

Heirman, A. L., and H. A. Wright. 1973. Fire in medium fuels of west Texas. Journal of Range Management 26:331-335.

Herbel, C. H., F. N. Ares, and R. A. Wright. 1972. Drought effects on a semidesert grassland range. Ecology 53:1084-1093.

Higins, S. I., W. J. Bond, And W. S. Trollope. 2000. Fire, resprouting and variability: a recipe for grass-tree coexistence in savanna. Journal of Ecology $88: 213-229$

Howe, H. F. 1994a. Managing species diversity in tallgrass prairie: assumptions and implications. Conservation Biology 8:691-704.

Howe, H. F. 1994b. Response of early- and late-flowering plants to fire season in experimental prairies. Ecological Applications 4:121-133.

HowE, H. F. 1995. Succession and fire season in experimental prairie plantings. Ecology 76:1917-1925.

Johnson, D. B., AND F. S. Guthery. 1988. Loafing coverts used by northern bobwhites in subtropical environments. Journal of Wildlife Management $52: 461-469$

Kaufman, D. W., E. J. Finck, And G. A. Kaufman. 1990. Small mammals and grassland fires. In: S. L. Collins and L. L. Wallace [EDS.]. Fire in North American tallgrass prairie. Norman, OK, USA: University of Oklahoma Press. p. 46-80.

Kopp, S. D., F. S. Guthery, N. D. Forrester, and W. E. Cohen. 1998. Habitat selection modeling for northern bobwhites on subtropical rangeland. Journal of Wildlife Management 62:884-895.

LEIF, A., AND L. SMITH. 1993. Winter diet quality, gut morphology and condition of northern bobwhite and scaled quail in West Texas. Journal of Field Ornithology 64:527-538.

Lusk, J. J., S. G. Smith, S. D. Fuhlendorf, and F. S. Guthery. 2006. Factors influencing northern bobwhite nest-site selection and fate. Journal of Wildlife Management 70:564-571.

McPherson, G. R. 1995. The role of fire in the desert grasslands. In: M. P. McClaran and T. R. van Devender [EDs.]. The desert grassland. Tucson, AZ, USA: The University of Arizona Press. p. 130-151.

Neuenschwander, L. F., S. H. Sharrow, and H. A. Wright. 1975. Review of tobosa grass (Hilaria mutica). The Southwestern Naturalist 20:255-263.

Neuenschwander, L. F., and H. A. Wright. 1984. Edaphic and microclimate factors affecting tobosagrass regrowth after fire. Journal of Range Management $37: 116-121$

Neuenschwander, L. F., H. A. Wright, and S. C. Bunting. 1978. The effect of fire on a tobosagrass-mesquite community in the Rolling Plains of Texas. The Southwestern Naturalist 23:315-337. 
National Oceanic and Atmospheric Administration. 2007. Paducah and Crowell, TX, United States. Asheville, NC, USA: National Climate Data Center. Available at: http://www.ncdc.noaa.gov/oa/ncdc.html. Accessed 15 November 2007.

Riggs, R. A., S. C. Bunting, And S. E. Daniels. 1996. Other wildlife conservation issues in range management: prescribed fire. In: P. R. Krausman [ED.]. Rangeland wildlife. Denver, CO, USA: Society for Range Management. p. 295-319.

Robel, R. J., J. P. Hughes, S. D. Hull, K. E. Kemp, and D. S. Klute. 1998. Spring burning: resulting avian abundance and nesting in Kansas CRP. Journal of Range Management 51:132-138.

Roberts, F. H., C. M. Britton, D. B. Wester, and R. G. Clark. 1988. Fire effects on tobosagrass and weeping lovegrass. Journal of Range Management 41:407-409.

SAS [computer program]. 2003. SAS/STAT Version 9.1 for windows. Cary, NC, USA: SAS Institute.

Scifres, C. J., R. R. HAHn, and J. H. Brock. 1971. Phenology and control of common broomweed on Texas rangelands. Journal of Range Management 24:370-373.

SeAstedt, T. R., J. M. Briggs, and D. J. Gibson. 1991. Controls of nitrogen limitation in tallgrass prairie. Oecologia 87:72-79.

Sharrow, S. H., And H. A. Wright. 1977. Proper burning intervals for tobosagrass in west Texas based on nitrogen dynamics. Journal of Range Management 30:343-346.

Soutiere, E. C., and E. G. Bolen. 1976. Mourning dove nesting on tobosa grassmesquite rangeland sprayed with herbicides and burned. Journal of Range Management 29:226-231.

Steuter, A. A. 1987. $\mathrm{C}_{3} / \mathrm{C}_{4}$ production shift on seasonal burns-Northern Mixed Prairie. Journal of Range Management 40:27-31.
Stubbendieck, J., S. L. Hatch, and C. H. Butterfield. 1992. North American range plants. Lincoln, NE, USA: University of Nebraska Press. 493 p.

ToWnE, G., AND C. OWENSBy. 1983. Annual broomweed [Gutierrezia drancunculoides (DC.) Blake] response to burning and mulch addition. Journal of Range Management 36:711-712.

TRoLLope, W. S. W. 1987. Effect of season of burning on grass recovery in the false thornveld of the eastern Cape. Journal of the Grassland Society of South Africa 4:74-77.

VAn AUKEn, 0. W. 2000. Shrub invasions of North American semiarid grasslands. Annual Review Ecology and Systematics 31:197-215.

van Wilgen, B. W., C. S. Everson, and W. S. W. Trollope. 1990. Fire management in southern Africa: some examples of current objectives, practices and problems. In: J. G. Goldhammer [ED.]. Fire in the tropical biota—ecosystem processes and global challenges. Berlin, Germany: Springer-Verlag. p. 179-215.

Wedin, D. A., and D. TILman. 1996. Influence of nitrogen loading and species composition on the carbon balance of grasslands. Science 271:1720-1723.

WRight, H. A. 1969. Effect of spring burning on tobosa grass. Journal of Range Management 22:425-427.

WriGHt, H. A. 1973. Fire as a tool to manage tobosa grasslands. In: E. V. Komarek and $H$. A. Wright [eds.]. Proceedings of the Tall Timbers Fire Ecology Conference No. 12; 8-9 June 1972; Lubbock, TX, USA. Tallahassee, FL, USA: Tall Timbers Research Station. p. 195-204.

Wright, H. A., and A. W. Balley. 1982. Fire ecology. New York, NY, USA: John Wiley and Sons. $501 \mathrm{p}$.

Yoder, C. K., T. W. Boutton, T. L. Thurow, and A. J. Midwood. 1998. Differences in soil water use by annual broomweed and grasses. Journal of Range Management 51:200-206. 